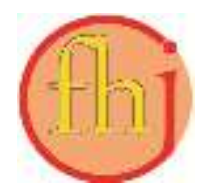

Faletehan Health Journal, 7 (3) (2020) 137-141

www. journal.Ippm-stikesfa.ac.id/ojs/index.php/FHJ

ISSN 2088-673X | e-ISSN 2597-8667

\title{
Peningkatan Keterampilan Klinik Melalui Penerapan Mini-CEX pada Mahasiswa Keperawatan
}

\author{
${ }^{1}$ Siska Evi Martina, ${ }^{2}$ Eva Hotmaria Simanjuntak \\ ${ }^{1}$ Program Studi Ners, Fakultas Farmasi dan Ilmu Kesehatan, Universitas Sari Mutiara Indonesia \\ ${ }^{2}$ Program Studi Profesi Bidan, Fakultas Farmasi dan Ilmu Kesehatan, Universitas Sari Mutiara Indonesia \\ *Corresponding Author: siskaevi21@gmail.com
}

\begin{abstract}
Abstrak
Kompetensi keperawatan yang masih terbatas dibeberapa wilayah Indonesia menjadi tantangan bagi penyelenggara pendidikan keperawatan. Kompetensi keperawatan harus dicapai oleh perawat melalui peningkatan keterampilan klinik. Mini-CEX salah satu metode yang mampu membantu mahasiswa keperawatan meningkatkan keterampilan kliniknya. Tujuan penelitian ini adalah mengidentifikasi pengaruh mini-CEX terhadap peningkatan keterampilan klinik pada mahasiswa keperawatan Universitas Sari Mutiara Indonesia. Metode penelitian ini adalah quasi experimen dengan teknik pengambilan total sampling terhadap 49 sampel yang terbagi menjadi 25 sampel kelompok intervensi dan 24 sampel kelompok kontrol. Kuesioner yang digunakan adalah kuesioner mini-CEX yang telah dimodifikasi. Hasil penelitian menunjukan ada perbedaan signifikan keterampilan mahasiswa keperawatan sebelum dan setelah dilaksanakan metode Mini-CEX ( $p$-value $=0,000)$. Keterampilan mahasiswa dalam praktek klinik setelah mendapatkan feedback melalui metode Mini-CEX meningkat (mean= 35,24) signifikan dibandingkan sebelum mendapatkan perlakukan miniCEX (mean= 25,56). Maka dari itu, mini-CEX sangat membantu mahasiswa keperawatan meningkatkan keterampilan klinik. Metode ini seharusnya diterapkan secara berkelanjutan di lahan praktek klinik mahasiswa.
\end{abstract}

Kata Kunci: Keterampilan Klinik; Kompetensi; Mahasiswa Keperawatan; Mini-CEX

\section{Improvement Clinical Skill Through the Implementation of Mini-CEX among Nursing Student}

\begin{abstract}
Lack of nursing competencies in Indonesia is still happened. The university or nursing high school who provided nursing education is one who responsible on this situation. Nursing skill should be achieved by nursing student to improve clinical skills. Mini-CEX is one of method which can be improve nursing student's skilss. Objective of this study to identify effectiveness of mini-CEX on improvement nursing student's clinical skills. Quasi experiment was conducted to reach 49 nursing student divide to 25 student as an intevention group and 24 student as a control group by total sampling. MiniCEX form was applied to measure clinical skill. This study found that nursing student's clinical skills before and after intervention was signficant different with pvalue $=0.000(<0.05)$. After student getting feedback, they were improve their skills (Mean=35.24), this showed that significant different from before intervention (Mean=25.56). Therefore, MiniCEX is a great clinical evaluation method to encourage and help student for improving their clinical skills. Mini-CEX should be applied contuniously in hospital.
\end{abstract}

Keywords: Clinical Skill; Competency; Mini-CEX; Nursing 


\section{Pendahuluan}

Kompetensi perawat saat ini berorientasi pada kualitas keterampilan yang dipengaruhi oleh kualitas pendidikan. Berdasarkan Undang Undang No 38 tahun 2014, untuk menguji perawat kompenten atau tidak yaitu melalui uji kompetensi. Direktorat Jendral Pendidikan Tinggi, Kementrian Riset dan Teknologi. Uji kompetensi menjadi tahap akhir dalam proses pendidikan keperawatan dan hal ini didukung mutu dari pendidikan keperawatan teserbut (Kemenrisetdikti, 2018)

Hasil Uji Kompetensi Perawat Indonesia periode Oktober 2018 di 5 institusi pendidikan tinggi keperawatan di Sumatera Utara, dari 302 perawat yang baru lulus, menunjukan lebih dari 50 \% (167 perawat) tidak kompeten dan hanya 135 perawat yang dinyatak kompeten (Kemenristek DIKTI, 2018). Rumah Sakit di Indonesia saat ini mengharuskan perawat memiliki Surat Tanda Registrasi (STR) dimana surat tersebut akan didapatkan jika mahasiswa tingkat akhir dinyatakan kompeten dari hasil ujian kompetensi perawat nasional. Hal ini menjadi tantangan bagi perawat di Indonesia menghadapi banyak tantangan. Maka dari itu, institusi pendidikan kesehatan yang memiliki program studi keperawatan harus meningkatkan kualitasnya, salah satunya melalui pengembangan metode evaluasi dan bimbingan klinik (Abdilah, 2016).

Mahasiswa keperawatan masih sangat terbatas dalam melakukan keterampilan klinik saat praktek di Rumah Sakit. Beberapa faktor yang mempengaruhi hal tersebut seperti fasilitas atau peralatan medis yang berbeda dari institusi pendidikan, metode bimbingan, keterbatasan role model di lahan praktek rumah sakit dan perawat yang tidak semua mampu membimbing mahasiswa di rumah sakit (AIPNI, 2014).

Metode bimbingan klinik yang diterapkan pada mahasiswa keperawatan sangat bervariasi dan memiliki kelebihan dan kekurangan masingmasing. Metode bimbingan yang sering diterapkan pada mahasiswa keperawatan saat ini adalah Direct Observation of Prosecudral Skills (DOPS), Objective Structured Clinical Examination (OSCE), laporan kasus, Beside Teaching, Case Based Discussion dan Mini Clinical Evaluation Examination (Mini-CEX (Kuo dkk, 2013). World Health Organization (WHO) menjelaskan miniCEX merupakan metode evaluasi yang memberikan kesempatan pada mahasiswa untuk meningkatkan keterampilannya bagi pasien dengan bebagai situasi, mahasiswa mendapatkan arahan dan evaluasi setelah diobservasi secara langsung oleh pembimbing (Ansari dkk., 2013; Kuo dkk., 2013). World Health Organization (WHO) menjelaskan bahwa mini-CEX memiliki feasibility baik bagi mahasiswa preceptor dan mahasiswa pada pendidikan kesehatan serta memenuhi kebutuhan capaian pembelajaran praktik sebesar 60\% (WHO, 2011).

Mini-CEX merupakan metode penilaian formatif yang cukup efektif dalam menilai performa mahasiswa pada level "does". Metode ini memiliki beberapa kelebihan seperti validitas dan reabilitas yang baik, memperoleh feedback dari preceptor, memberikan kesempatan yang banyak pada mahasiswa untuk menunjukkan kemampuannya pada berbagai kasus, setting dan langsung dengan pasien. Mini-CEX juga sangat membantu preceptor untuk mengaplikasikan pengetahuan dan pengalamannya dan meningkatkan kepercayaan diri untuk bisa menjadi role model (Huang, 2015).

Penelitian ini mengidentifikasi pengaruh metode mini-CEX terhadap keterampilan klinik mahasiswa keperawatan di Rumah Sakit Umum Sari Mutaiar Lubuk Pakam. Penenlitian ini perlu segera dilakukan merujuk kepada tuntutan dan kebutuhan perawat yang lebih terampil. Sehingga mahasiswa keperawatan dari pendidikan menjadi tenaga kesehatan yang terampil dan kompeten.

\section{Metode Penelitian}

Penelitian ini merupakan penelitian eksperimen semu (Quasi-exsperiment) tanpa randomisasi karena subyek penelitian sudah terbagi dalam kelompok berdasarkan ruangan praktik klinik. Populasi dalam penelitian ini adalah seluruh mahasiswa aktif pada program studi Diploma III Keperawatan Universitas Sari Mutiara Indonesia yang akan melakukan praktik klinik di RS Sari Mutiara Lubuk Pakam. Penelitian ini terdapat dua kelompok yaitu kelompok intervensi diberikan metode mini-CEX sedangkan kelompok kontrol melakukan penilaian seperti biasa dilakukan yaitu dengan penilaian Ujian Pengamatan dengan Daftar Tilik (UPDT). Teknik pengambilan sampel yang digunakan adalah total sampling. Sampel yang dipilih pada penelitian ini adalah mahasiswa program studi keperawatan Universitas Sari 
Faletehan Health Journal, 7 (3) (2020) 137-141

www. journal.Ippm-stikesfa.ac.id/ojs/index.php/FHJ

ISSN 2088-673X | 2597-8667

Mutiara Indonesi semester III-VI yang memenuhi kriteria inklusi: 1) Mahasiswa semester III-VI prodi D-III Keperawatan yang melaksanakan pembelajaran praktik dengan kehadiran $100 \%$, 2) Telah lulus ujian teori dan laboratorium, 3) menyetujui ikut dalam penelitian. Sampel untuk prodi DIII keperawatan pada kelompok intervensi penelitian ini sebanyak 25 orang dan kelompok kontrol sebanyak 24 orang, sehingga total sampel sebanyak 49 orang.

Kuesioner yang digunakan pada penelitian ini adalah format penilaian mini-CEX yang telah di modifikasi yang mencakup 7 kompetensi keterampilan seperti kemampuan anamnesis, kemampuan pemeriksaan fisik, kualitas profesionalisme, keputusan diagnosa, tata laksana, kemampuan konseling, dan organisasi. Setiap kompetensi keterampilan dinilai aspek kognitif, afektif, dan psikomotor dengan nilai terendah 0 dan nilai tertingi 3 pada masing masing aspek. Sehingga skor penilairan kumulatif 0 sampai 63. Mahasiswa dengan skor $<32$ dinyatakan kurang terampil dan $\geq 32$ mahasiswa terampil. Penelitian ini telah dinyatakan lolos uji etik berdasarkan No 406/KEPK/FKUMSU/2020. Proses perijinan juga diberikan dari LPPM Universitas Sari Mutiara Indonesia dan disetujui oleh Direktur Rumah Sakit Umum Sari Mutiara Lubuk Pakam.

\section{Hasil dan Pembahasan}

Tabel 1. Distrisbusi Ferekuensi karakteristik mahasiswa keperawatan pada kelompok control dan kelompok Intervensi $(n=49)$

\begin{tabular}{lcccc}
\hline Variabel & \multicolumn{2}{c}{$\begin{array}{c}\text { Control } \\
\text { Goup } \\
(\mathbf{n = 2 4})\end{array}$} & \multicolumn{2}{c}{$\begin{array}{c}\text { Intervensi } \\
\text { Group } \\
(\mathbf{n = 2 5})\end{array}$} \\
\cline { 2 - 5 } & $\mathbf{n}$ & $\mathbf{\%}$ & $\mathbf{n}$ & $\mathbf{\%}$ \\
\hline Usia & & & & \\
20 tahun & 5 & 20,8 & 5 & 20 \\
21 tahun & 15 & 62,5 & 9 & 36 \\
22 tahun & 4 & 16,7 & 11 & 44 \\
\hline Jenis Kelamin & & & & \\
$\quad$ Laki-laki & 10 & 41,7 & 8 & 32 \\
$\quad$ Perempuan & 14 & 58,3 & 17 & 68 \\
\hline Total & 24 & 100 & 25 & 100 \\
\hline
\end{tabular}

Tabel 1 menunjukkan gambaran sampel pada penelitian ini. Mayoritas kelompok intervensi berusia 22 tahun (44\%) sedangkan kelompok kontrol 21 tahun $(62,5 \%)$. Jenis kelamin pada kelompok intervensi mayoritas adalah perempuan (68\%) dan serupa dengan kelompok kontrol 58,3 $\%$ adalah perempuan. Hal ini memang sangat umum pada pendidikan keperawatan yang didominasi oleh perempuan sebagai mahasiswa terbanyak dibandingkan jurusan sosial lainnya. Mayoritas usia pada kelompok intervensi adalah 22 tahun, hal ini dikarenakan saat pelaksanaan penelitian mahasiswa tingkat akhir yang mendapatkan kesempatan lebih banyak untuk dinilai secara mini-CEX.

Tabel 2. Distribusi Frekuensi Mini-CEX pada kelompok Intervensi $(n=25)$

\begin{tabular}{lcc}
\multicolumn{1}{c}{ Variabel } & n & \% \\
\hline $\begin{array}{l}\text { Kepuasan mahasiswa } \\
\text { terhadap mini-CEX }\end{array}$ & & \\
$\quad$ Memuaskan & 8 & 32 \\
$\quad$ Superior & 17 & 68 \\
\hline $\begin{array}{l}\text { Penilaian keseluruhan } \\
\text { keterampilan }\end{array}$ & & \\
$\quad$ Kurang Memuaskan & 4 & 16 \\
$\quad$ Memuaskan & 18 & 72 \\
$\quad$ Superior & 3 & 12 \\
\hline Total & $\mathbf{2 5}$ & $\mathbf{1 0 0}$ \\
\hline
\end{tabular}

Penelitian ini juga mengidentifikasi tingkat kepuasan mahasiswa keperawatan pada kelompok intervensi terkait pelaksaan mini-CEX. Mayoritas mahasiswa (68\%) menyatakan pelaksanaan miniCEX sangat memuaskan atau superior. Hal ini dikarenakan pengalaman pertama mahasiswa keperawatan melakukan praktek klinik dengan diobservasi, didampingi, dinilai, dan mendapatkan feedback secara langsung. Sehingga proses praktik dan bimbingan menjadi lebih baik dan mahasiswa mampu meningkatkan keterampilannya berdasarkan feedback yang didapat. Mini-CEX dillakukan oleh preceptor kepada mahasiswa keperawatan yang praktek di RS umum Sari Mutiara Lubuk Pakam melalui observasi selama 15 menit saat mahasiswa berinterakti dan melakukan tindakan keperawatan kepada pasien dan keluarga. Setelah mahasiswa selesai dari pasien, preceptor memberikan feedback selama 5 menit terkait hal yang telah dilakukan dan yang harus dilakukan selanjutnya dalam peningkatan asuhan keperawatan. Selain itu $72 \%$ mahasiswa menunjukan hasil yang memuaskan setelah menerima feedback dan hanya $16 \%$ masih kurang memuaskan. 
Tabel 3. Perbedaan Keterampilan Klinik Mahasiswa Keperawatan Dengan Metode Mini-CEX

\begin{tabular}{|c|c|c|c|c|}
\hline Variabel & Perlakuan & $\begin{array}{c}\text { Mean } \pm \text { Std } \\
\text { Deviasi }\end{array}$ & $\mathbf{t}$ & p-value \\
\hline $\begin{array}{l}\text { Keterampilan } \\
\text { klinik mahasiswa } \\
\text { keperawatan } \\
\text { dengan metode } \\
\text { mini-CEX }\end{array}$ & $\begin{array}{l}\text { Pre- intervensi } \\
\text { Post-Intervensi }\end{array}$ & $\begin{array}{l}25,56 \pm 3,75 \\
35,24 \pm 5,14\end{array}$ & - $\quad 7,685$ & 0,000 \\
\hline
\end{tabular}

Berdasarkan hasil uji t berpasangan (paired sample t test) menunjukan nilai signifikansi sebesar $0,000(\mathrm{p}<0,05)$, yang berarti bahwa ada perbedaan signifikan keterampilan mahasiswa keperawatan sebelum dan setelah dilaksanakan metode miniCEX. Hal ini mengindikasikan metode mini-CEX signifikan berpengaruh dalam meningkatkan keterampilan mahasiswa keperawatan. Terlihat dari keterampilan mahasiswa dalam praktek klinik setelah mendapatkan feedback melalui metode mini-CEX meningkat (mean= 35,24) signifikan dibandingkan sebelum mendapatkan perlakukan mini-CEX (mean= 25,56) (Tabel 3).

Penelitian ini mengidentifikasi tingkat kepuasaan mashasiswa dengan perlakuan miniCEX. Hasil penelitian menujukan mayoritas mahasiswa puas degan metode mini-CEX. Hal ini sejalan dengan tingkat kepuasan mahasiswa terhadap pelaksanaan evaluasi melalui mini-CEX. Mini-CEX dapat meningkatkan proses pembelajaran klinik mahasiswa keperawatan melalui penjelasan perkembangan kompetensinya dan bahkan kelemahan yang sering dilakukan saat memberikan asuhan keperawatan. Setiap mahasiswa sangat membutuhkan saran dan evaluasi yang positif untuk mengurangi tingkat stress selama praktek klinik (Lita, 2013; Mansourian dkk, 2013). Mahasiswa keperawatan saat ini dituntut harus memiliki kompetensi yang telah ditetapkan maka melalui mini-CEX proses praktek klinik dapat membantu mahasiswa mencapai kompetensinya.

Mini-CEX pada peneltian ini menunjukan pengaruh signifikan terhadap perubahan keterampilan mahasiswa keperawatan yang praktek di RS Sari Mutiara Lubuk Pakam. Hasil penelitian ini sejalan dengan hasil penelitian yang dilakukan Moghadam dkk (2016) yang menunjukan perbedaan signifikan nilai mean keterampilan klinik mahasiswa anestesi pada kelompok kontrol dan kelompok intervensi. WHO menyatakan bahwa pemberian feedback menggunakan metode mini-CEX membuat mahasiswa lebih baik mencapai kompetensi pembelajaran klinik. Melalui mini-CEX, preceptor memberikan feedback kepada mahasiswa sehingga mahasiswa menjadi lebih terbuka atas hal yang telah dilakukan kepada pasien.

Mahasiswa mendapatkan kesempatan dinilai dan mendapat umpan balik sebagai evaluasi yang telah dilakukan dan masukan untuk meningkatkan keterampilannya (Sudarso dkk, 2016; Lita, 2013; Habibi dkk, 2013). Preceptor memberikan evaluasi atas keterampilan yang dilakukan mahasiswa secara langsung dan objektif dengan penjelasan bagaimana dan apa yang harus dilakukan untuk meningkatkan keterampilan tersebut. Mahasiswa harus tetap mendapat apresiasi atas hal yang telah dilakukan, tidak memberikan evaluasi dengan teknik mengkritik. Melalui penjelasan yang disampaikan, mahasiswa akan lebih menerima dan memahami bagaimana untuk meningkatkan kompetensinya. Hal ini sangat berguna saat mereka bukan lagi menjadi mahasiswa tetapi menjadi perawat sesungguhnya.

Hal serupa juga dipaparkan oleh Sudarso dkk (2016) bahwa kesempatan yang diperoleh mahasiswa untuk menerima feedback dan saran guna mengembangkan kemampuan keterampilannya akan sangat memotivasi, dibandinngkan hanya mengkritik hal yang sudah dilakukan. Kelebihan lain dari metode mini-CEX adalah menstimuli proses evaluasi dalam diri mahasiswa tersebut seperti refleksi diri, respon emosi, dan motivasi. Proses tersebut akan membuat mahasiswa menjadi lebih yakin untuk meningkatkan keterampilan. Preceptor tidak hanya memberikan nilai atau menguji mahasiswa namun hubungan kerja sama dapat terwujud melalui pemberian feedback sehingga mahasiswa juga merasa menjadi bagian dari tempat praktek, semakin antusias menjalankan praktek dan meningkatkan keterampilan klnik selama pratek. 
Faletehan Health Journal, 7 (3) (2020) 137-141

www. journal.Ippm-stikesfa.ac.id/ojs/index.php/FHJ

ISSN 2088-673X | 2597-8667

\section{Simpulan}

Penelitian ini menunjukan ada perbedaan signifikan keterampilan mahasiswa keperawatan sebelum dan setelah dilaksanakan metode miniCEX. Metode mini-CEX secara signifikan berpengaruh dalam meningkatkan keterampilan mahasiswa keperawatan.

\section{Referensi}

Abdilah. (2016). Analisis Faktor-Faktor Yang Mempengaruhi Kelulusan Uji Kompetensi Ners Indonesia. J. Penelit. Adm. Publik, 2, 373-380.

AIPNI. (2014). Materi Pelatihan Preceptorship (tidak dipublikasikan). Yogyakarta : STIKes Almaata (in Bahasa Indonesia).

Al Ansari A., Ali, S.K., \& Donnon, T. The construct and criterion validity of the miniCEX: a meta-analysis of the published research. Acad Med. 2013, 88 (3) : 413 - 420. doi:10.1097/ACM.0b013e318280a953

Djuria, S.A., \& Afandi, M. (2013). Development of measurement tool Mini-CEX (Mini Clinical Evaluation) as an evaluation tool of nursing students in teaching hospital of Universitas Muhammadiyah Yogyakarta. GSTF International Journal of Nursing and Health Care (JNHC), 1(1): 127-132.

Habibi, H., Khaghanizade, M., Ebadi, A., \& Sayedmazhari, M. 2013. Comparison of the Effect of Modern Assesment Methods (DOPS and Mini-CEX) with traditional method on Nursing students'Clinical Skills : A Randomized Trial. Iranian Journal of Medical Education, 13(5) :364-372.
Huang, S. Y. (2015). The Experience Of MiniClinical Evaluation. BMJ Open , A1A53.

Kemenristek DIKTI. ( 2018). Data Statistik Pendaftar lulus dan tidak lulus.Registrasi Online Uji Kompetensi NERS.

Kuo, C.L., Shou, J.P., Maw, S.L., Chih, W.Y., \& H, P.K. (2013). Develompment and implementation of a mini-clinical evaluation exercise (Mini-CEX) program to asses the clinical competencies of internal medicine residents: from faculty development to curriculum evaluation. BMC Medical Education, 13 (13): 1472-1476.

Lita, B.F. (2013). Comparison of perceptions of nursing internship program and preseptor on Mini-CEX implementation in Education Hospital. Underthesis. Muhammadiyah University of Yogyakarta.

Moghadam, F.A., Sahebalzamani, M., Fatemah, M., Farahani, H., \& Gharabagh, Z.A. (2016). A comparative analysis of the effect of MiniCEX and conventional assesment methods on clinical skill ini anesthesiology students of School of Paramedicine, Hamedan University of Medical Sciences. Journal of Advances in Medical Education (JAMED), 1 (3): 60-68.

Sudarso, S., Rahayu, G. R., \& Suhoyo, Y. (2016). How does feedback in mini-CEX affect students' learning response? International Journal of Medical Education, 7 , 407-413,

https://doi.org/10.5116/ijme.580b.363d

WHO.(2011). Panduan Pembelajaran Praktik Klinik Kebidanan dengan Pendekatan Preceptorship dan Mentorship. Jakarta: Pusat Pendidikan dan Pelatihan Tenaga Kesehatan. 